industries by way of recruits to their scientific staffs. With the great increase in scientific control in industry there has arisen a demand for a varied army of scientific workers, ranging from routine semiskilled testers to fully trained research specialists. By means of a questionnaire Dr. Rudge has gained information that shows the distribution of the demand for scientific workers in the different grades.

This investigation produced the following main conclusions. A large proportion of the chemical firms in the area investigated employ small laboratory personnel (less than ten employees). These small organizations commonly employ unqualified recruits, and it is in the main the larger laboratories that require graduates and research workers. A great preference is shown for recruits of about matriculation standard with a knowledge of industrial method and technique. For every graduate required for the specialized work of research development more than nine undergraduates are required for laboratory routine. The question of the training of these un- qualified employees is one that requires greater cooperation between industry and teachers, especially in the technical colleges.

Dr. F. S. Sinnatt, speaking on the Fuel Research Coal Survey, said that the work of the Department of Scientific and Industrial Research can be divided into two sections: the utilization of coal, and the survey of the coalfields of Great Britain. Different types of coal are needed for use in coking, gas manufacture, steam raising, household use and hydrogenation; wide variation may occur in the composition of a seam within the area covered by one mine, with consequent changes in its suitability for these different purposes. The control of such variation is of primary importance to the consumer and must be the basis of any improvement in the utilization of coal.

As a result of the work already done, it can now be said about certain important seams in different coal. fields that every major variation in the composition is known, and that it can be forecast for any spot within narrow limits.

\title{
The Waite Agricultural Research Institute, South Australia
}

$\mathrm{T}$

HE Waite Agricultural Research Institute was established at Glen Osmond, near Adelaide, South Australia, in 1925, as a result of the late $\mathrm{Mr}$. Peter Waite's gift to the University of Adelaide for the purpose of furthering the cause of education and research in agriculture and allied subjects. The total value of the bequest was estimated at $£ 100,000$.

The University Council decided that the prineipal objective of the Institute should be to enlarge the stock of knowledge relating to agriculture in the widest sense, and pass it on to those actively engaged in production, as farmers or pastoralists. Two chairs were established: one in agriculture and one in agricultural chemistry. Prof. A. E. V. Richardson was appointed Waite professor of agriculture and first director of the Waite Institute; Prof. J. A. Prescott was appointed Waite professor of agricultural chemistry. Since the commencement of active work early in 1925, the number of research workers stationed at the Institute has risen from five to forty, and the annual income from $£ 8,000$ to approximately $£ 25,000$, apart from a yearly grant by the Australian Commonwealth Council for Scientific and Industrial Research for the maintenance of its Division of Soils, which has its headquarters at the Waite Institute. After thirteen years of eminent service, Prof. Richardson has now resigned to occupy the position of Deputy Chief Executive Officer of the Council for Scientific and Industrial Research, and Prof. Prescott has been appointed director of the Waite Institute.

Prof. Richardson is a graduate of the University of Adelaide and was acting director of agriculture in South Australia in 1911. From 1911 until 1924 he was superintendent of agriculture for Victoria and visited the United States and Canada to report on agricultural research and education in 1918. From 1919 until 1924 he was director of the School of Agriculture in the University of Melbourne. Prof. Richardson visited South Africa, Europe, America,
Japan and Java in 1926 and was a delegate to the Imperial Agricultural Research Conference at London in 1927. He was appointed a member of the Executive of the Australian Council for Scientific and Industrial Research in 1927, shortly after its inception in 1926, and was official agricultural adviser to the Australian delegation to the Imperial Conference at Ottawa in 1932. He was elected first president of the Australian Institute of Agricultural Science, which was established in 1935.

Prof. Prescott is a native of Lancashire and graduated in chemistry at the University of Manchester. In addition to post-graduate experience at Manchester, he worked at Rothamsted Experimental Station with Sir John Russell and at the University of Leipzig with Dr. Wolfgang Ostwald. From 1916 until 1923 he was chief chemist to the Royal Agricultural Society of Egypt and superintendent of field experiments at the Society's Experimental Farm at Bahtim. His work in Egypt concerned problems of soil fertility associated with Egyptian agriculture and the manuring, spacing and irrigation of wheat, maize and cotton.

In 1929, Prof. Prescott was appointed chief of the Division of Soils of the Council for Scientific and Industrial Research at the Waite Institute. His work in Australia has related chiefly to the classification and geographical distribution of soils, and his bulletin on the soils of Australia, published in 1931, has become a standard reference book throughout Australia. Prof. Prescott has travelled extensively in Australia and New Zealand and is familiar with agricultural and pastoral conditions in all the Australian States and the Northern Territory. $\mathrm{He}$ was federal president of the Australian Chemical Institute in 1936-37.

The association of Richardson and Prescott over the first thirteen years of the Waite Institute has proved of immense value to agricultural science in Australia. 